\title{
ZWIĄZKI KS. JÓZEFA PASTUSZKI Z AKADEMIĄ DUCHOWNĄ W PETERSBURGU I KATOLICKIM UNIWERSYTETEM LUBELSKIM
}

\begin{abstract}
Wstęp
Niniejsze opracowanie zostało przygotowane z okazji 100-lecia istnienia Katolickiego Uniwersytetu Lubelskiego Jana Pawła II. W Uniwersytecie pracowało wiele osób, niektóre były z nim związane od samego początku jego działalności. Do nich m.in. należy kapłan diecezji sandomierskiej ks. prof. dr hab. Józef Pastuszka, którego życie przypadło na okres ogromnych przezmian, jakie zachodziły w Europie i w dziejach narodu polskiego.

Urodził się, kiedy Polski nie było na mapie Europy, naukę w szkole rozpoczynał w języku rosyjskim, był tułaczem w czasie pierwszej wojny światowej i później w 1917 r. w Petersburgu wraz z innymi Polakami przeżył rewolucję październikową. W listopadzie 1918 r. cieszył się z odrodzenia Polski po dziesięcioleciach niewoli. Z kolei w roku 1939 i w latach okupacji doświadczał skutków drugiej wojny światowej, poszukiwany przez gestapo musiał się ukrywać. Wojna się zakończyła, ale przyszły lata represji wobec społeczeństwa i Kościoła. W latach pięćdziesiątych represje te dotknęły ks. Józefa Pastuszkę. W 1952 r. został usunięty z uczelni, gdzie po kilku latach w 1956 r. powrócił do pracy. Zmarł w Sandomierzu na początku roku 1989, w którym nastąpiły nowe okoliczności społeczno-polityczne. Tak realizowało się aktywne życie ks. Józefa Pastuszki. Warto więc bliżej poznać jego osobę i działalność oraz prześledzić jego związki z Akademią Duchowną w Petersburgu i z powstałym w 1918 r. Uniwersytetem Lubelskim.
\end{abstract}

\section{Rys biograficzny}

Józef Adam Pastuszka urodził się 28 lutego 1897 r. we wsi Rzeczniówek, gmina i parafia Rzeczniów koło lłży (w ówczesnej guberni radomskiej pod zaborem rosyjskim), w rodzinie rolniczej Franciszka i Tekli z Wróblewskich. Otrzymał staranne wychowanie w duchu katolickim i patriotycznym. Przez całe życie łączyły go więzy z rodzicami, rodzeństwem, jak również miłość do Ojczyzny ${ }^{1}$. Od siódmego

1 Zob. J. P[astuszka], Z życia parafialnego. Sandomierz. Święto narodowe, „Kronika Diecezji Sandomierskiej” [dalej: KDS] 18 (1925), s. 130-132; J. Pastuszka, Psychologia ogólna, Lublin 1961, s. 268 (punkt h). 
roku życia uczęszczał do miejscowej czteroklasowej szkoły początkowej², po jej ukończeniu do 6-klasowego państwowego progimnazjum męskiego w Sandomierzu z zaliczeniem dwóch klas niższych. W swoich wspomnieniach odnotował, że językiem wykładanym był język rosyjski, tylko język polski i religia w wymiarze dwóch godzin tygodniowo były prowadzone po polsku³.

Przyszły profesor Katolickiego Uniwersytetu Lubelskiego, ks. Józef Adam Pastuszka, w 1912 r. rozpoczął studia w Wyższym Seminarium Duchownym w Sandomierzu i realizował je do pierwszej wojny światowej, która w następstwie działań wojennych w 1915 r. wraz z rodzicami i rodzeństwem zaprowadziła go na Wschód w okolice Brześcia. Kiedy udało mu się przedostać do Petersburga, podjął przez dwa lata kontynuację studiów w tamtejszym seminarium duchownym. Rektorem Akademii Duchownej był wówczas ks. Idzi Radziszewski. Tam też w Wielką Sobotę 1917 r., jako alumn diecezji sandomierskiej, otrzymał święcenia subdiakonatu z rąk bpa Edwarda Roppa. Przez rok 1917/1918 był studentem Akademii w Petersburgu ${ }^{4}$.

W lipcu 1918 r. subdiakon Józef Adam Pastuszka wrócił do kraju. Mając ukończony pierwszy rok studiów w Petersburgu ${ }^{5}$ został przez sandomierską władzę diecezjalną skierowany na studia do Innsbrucka (Austria) na wydział teologiczny, z zamiarem studiowania teologii dogmatycznej.

W okresie studiów, 15 sierpnia 1919 r., w katedrze w Sandomierzu przyjął święcenia kapłańskie z rąk biskupa pomocniczego Pawła Kubickiego. Po ukończeniu studiów ks. Józef Pastuszka przedstawił rozprawę doktorską (De privilegio canonis) i zdał egzaminy po czym pod koniec października 1920 r. otrzymał dyplom doktorski ${ }^{6}$. Następnie zapisał się na Wyższy Instytut Filozofii Scholastycznej w Innsbrucku, gdzie w 1921 r. uzyskał tytuł licencjata filozofii. Przed rozpoczęciem nowego roku otrzymał od września nominację na profesora filozofii (wykładał psychologię, etykę i teodyceę) i prefekta alumnów Wyższego Seminarium Duchownego w Sandomierzu ${ }^{7}$ a także był lektorem języka niemieckiego w niższym seminarium. Jednocześnie kontynuował przerwane studia filozoficzne dojeżdżając do Innsbrucka. Napisał pracę: De origine potestatis civilis iuxta R. Bellarminum i w 1925 r. uzyskał doktorat $\mathrm{z}$ filozofii.

2 Dnia 18 września 2005 roku Zespół Szkół w Rzeczniowie za patrona placówki obrał swego Rodaka ks. prof. dr. hab. Józefa Pastuszkę (zob. Aneks).

3 J. Pastuszka, Sandomierskie wspomnienia szkolne z lat 1908-1912, do druku przygotował J. M. Małecki, „Studia Historyczne” 29 (1965), s. 595-619.

4 B. Ussas, Akademia Duchowna w Petersburgu, w: Encyklopedia Katolicka, t. 1, A i $\Omega$ Babtyści, red. F. Gryglewicz, R. Łukaszczyk, Z. Sułowski, Lublin 1995, kol. 213-214.

5 Na świadectwie ukończenia pierwszego roku studiów widnieje podpis ks. Idziego Radziszewskiego Archiwum Diecezji Sandomierskiej [dalej: ADS], Akta personalne ks. Józefa Pastuszki (1919-1989) [dalej: Ap JP].

6 Z czasem dyplom doktorski został nostryfikowany przez Uniwersytet Stefana Batorego $\mathrm{W}$ Wilnie.

7 ADS, Ap JP, Nominacja z dnia 20 VIII 1921 r. 
W maju 1930 r. przeprowadził coloquium habilitacyjne na wydziale Teologicznym Uniwersytetu Jagiellońskiego w Krakowie na podstawie rozprawy: Niematerialność duszy ludzkiej u św. Augustyna i uzyskał tytuł docenta filozofii, który zatwierdziło Ministerstwo Wyznań Religijnych i Oświecenia Publicznego R. P. już pod koniec maja tego roku. Po czym został zastępcą profesora na Wydziale Teologicznym Uniwersytetu Warszawskiego.

Ksiądz Profesor od 1938 r. był tajnym szambelanem papieskim, od 1964 prałatem honorowym papieża, od 1951 r. kanonikiem gremialnym Kapituły Sandomierskiej, od 1974 r. prałatem tejże Kapituły. Za swoją działalność w 1938 r. został odznaczony Złotym Krzyżem Zasługi i w 1978 r. Krzyżem Kawalerskim Orderu Odrodzenia Polski ${ }^{8}$.

Ksiądz Profesor zmarł 13 stycznia 1989 r. w Sandomierzu ${ }^{9}, 17$ stycznia w katedrze sandomierskiej odbyły się uroczystości pogrzebowe emerytowanego pracownika naukowego Katolickiego Uniwersytetu Lubelskiego, wykładowcy filozofii i psychologii.

W czasie uroczystości m.in. głos zabrał Kazimierz Przybyłko, Sekretarz Lubelskiego Oddziału Polskiego Towarzystwa Psychologicznego i uczeń zmarłego Profesora. „Żegnamy dziś człowieka - powiedział - o niezwykłych cechach charakteru i dobroci, śp. księdza Profesora Dr. Hab. Józefa Pastuszkę, nestora polskich psychologów, szczególnie zasłużonego dla ośrodka lubelskiego i Katolickiego Uniwersytetu. Mimo wielu innych propozycji pracy (Lwów, Warszawa) wybrał ten Uniwersytet i tu od okresu międzywojennego pracował, organizował Wydział Filozofii, i tu tworzył swoje prace naukowe. Tu też zaskarbił sobie wielki szacunek, uznanie najbliższych współpracowników i wielką miłość ze strony studentów. Był ich wielkim rzecznikiem, przewodnikiem i życzliwym doradcą - opiekunem, żeby nie powiedzieć - ojcem.

Każde jego pojawienie się w różnych miejscach Uniwersytetu - było okazją do życzliwych rozmów, uśmiechów, porad w różnych trudnych wówczas sytuacjach, w tym również - materialnych. Dla każdego znalazł chwilę czasu, uśmiech i życzliwą radę - choćby nawet $\mathrm{w}$ drodze na wykład. Cieszył się ogromną sympatią wśród studentów. Był dla nas mistrzem słowa i czynu. Był dla nas niekłamanym autorytetem choć ten autorytet nie paraliżował studentów, a zmuszał do intelektualnego wysiłku. Był też dla mnie pierwszym egzaminatorem na pierwszym roku studiów, którego z szacunkiem wspominam. Jego cechy osobowości wpływały stymulująco na rozwój i poczucie bezpieczeństwa studentów.

Ksiądz Profesor pełnił wiele odpowiedzialnych funkcji uniwersyteckich - kierownika Sekcji Psychologii, dziekana Wydziałów Nauk Humanistycznych i Filozo-

8 Okres pracy księdza profesora w Katolickim Uniwersytecie Lubelskim szczegółowo będzie omówione w następnym punkcie.

9 (c. b.), Zmarł ks. prof. prałat Józef Adam Pastuszka, „Słowo Powszechne” 42 (1989), nr 12, z dnia 17 I 1989 r., s. 6; J. Lewiński, Kronika - z życia diecezji, KDS, 82 (1989), nr 3-4, s. $87-88$. 
fii, a przez pewien okres pełnił funkcję rektora KUL-u w okresie wyjątkowo trudnym, bo stalinowskim.

Mimo licznych prac i obowiązków znajdował czas na rozmowy i dyskusje z psychologami praktykami - zauważał problemy i podsuwał sposoby ich rozwiązań, starannie je analizując. Był współtwórcą i organizatorem Oddziału Lubelskiego - Polskiego Towarzystwa Psychologicznego. Pragnę też jako przedstawiciel tegoż Towarzystwa pożegnać śp. księdza Profesora - w zadumie i modlitwie - jako człowieka wielkiego serca i dobroci. Non omnis moriar - bo Twoje dzieła i Twoja dobroć - żyć będą we wdzięcznej pamięci Twych uczniów, wychowanków i studentów. Zostanie w naszej pamięci jako homo Bonus, homo Sapiens et homo Dei. Profesor Pastuszka był człowiekiem głębokiej wiary, nadziei i dobroci. Człowiekiem nauki, serdeczności i życzliwości dla bliźnich. Te cechy osobowościowe wyróżniały go od innych" 10 .

Dnia 21 stycznia 1989 r. śp. ks. Józef Adam Pastuszka został pochowany w rodzinnej parafii w Rzeczniowie. Z kolei 26 stycznia społeczność akademicka KUL uczestniczyła we Mszy świętej w intencji śp. ks. Józefa Adama Pastuszki, zasłużonego wychowawcy wielu pokoleń studentów.

Papież Jan Paweł II przesłał do biskupa sandomierskiego Edwarda Materskiego telegram z okazji pogrzebu profesora w Sandomierzu: „Wraz z całą wspólnotą Katolickiego Uniwersytetu Lubelskiego uczestniczę duchowo w pogrzebie księdza profesora Józefa Pastuszki, gorliwego kapłana diecezji sandomiersko-radomskiej, który wychował całe pokolenie swoich uczniów i trwale zapisał się w historii katolickiej uczelni. Modlę się gorąco, aby Miłosierny Bóg przyjął go do swojej chwały i obdarzył pokojem. Wieczny odpoczynek racz mu dać Panie. Wszystkim uczestnikom liturgii pogrzebowej i całej wspólnocie diecezjalnej z serca błogosławię: W imię Ojca i Syna i Ducha Świętego - Jan Paweł II, papież"11.

$\mathrm{Na}$ koniec warto przytoczyć fragment życiorysu własnego księdza profesora: „W moim życiu połączyłem dwa powołania - kapłaństwo i profesurę. Było to powiązanie szczęśliwe, które wypełniło mi życie. Moje kapłaństwo połączyłem z pracą intelektualną, naukową. Obie te funkcje, a właściwie oba powołania, nie były dowolnie wybrane, lecz jakby narzucone przeze mnie samego, gdyż obie były wyrazem mojej osobowości, obie się uzupełniały. Nigdy nie żałowałem, że zostałem kapłanem i profesorem. Swą profesurę uważałem za jedną formę mojej misji kapłańskiej, a moje prace filozoficzne czy psychologiczne były w jakiejś formie religijne (Sandomierz, 6 XII 1978)"12.

10 P. K. Kuty, I. Ziemiński, Diariusz wydarzeń uniwersyteckich, styczeń-grudzień 1989, „Zeszyty Naukowe Katolickiego Uniwersytetu Lubelskiego” 32 (1989), nr 1-4, s. 131-132.

11 Zob. (las), Uroczystości pogrzebowe śp. ks. prof. J. A. Pastuszki, „Słowo Powszechne”, 42 (1989), nr 15, z dnia 20 I 1989 r., s. 1, 6.

12 ADS, Ap JP, k. 12. 


\section{Student Akademii Duchownej w Petersburgu i profesor Katolickiego Uniwersytetu Lubelskiego}

Przyszły profesor, jak już wspomniano, w 1912 r. rozpoczął studia w Wyższym Seminarium Duchownym w Sandomierzu i realizował je do pierwszej wojny światowej, która w następstwie działań wojennych w 1915 r. zaprowadziła go na Wschód. Kiedy udało mu się przedostać do Petersburga, podjął przez dwa lata kontynuację studiów w seminarium duchownym.

Następnie przez rok 1917/1918 był studentem Akademii Duchownej w Petersburgu ${ }^{13}$, gdzie swój początek, niejako „,prehistorię” miała uczelnia katolicka ${ }^{14}$. Ówczesny rektor ks. Idzi Radziszewski ${ }^{15}$ podjął organizację Uniwersytetu Lubelskiego mimo niezrozumienia przez wielu samej idei uniwersytetu katolickiego ${ }^{16}$. Tam zostały zapoczątkowane ,prace organizacyjne nad przyszłym uniwersytetem katolickim w Polsce, o czym my studenci byliśmy informowani choćby dlatego, że uważano nas za przyszłych studentów nowej uczelni ${ }^{17}$. Twórca KUL-u był wtedy rektorem Akademii w Petersburgu, a grono profesorów, którzy później stanowili pierwszą kadrę naukową KUL-u, to ówcześni profesorowie tej Akademii. Kiedy w marcu 1918 r. został zawarty pokój pomiędzy ówczesną Rosją a Niemcami ${ }^{18}$, tworzącą u siebie nowe formy życia społecznego i państwowego, otwarły się perspektywy powrotu do Ojczyzny przed Polakami, których zawierucha wojenna wypędziła z kraju. Liczono się również z tym, że w nowych warunkach państwowych Akademia Duchowna w Petersburgu będzie istniała tylko do końca roku akademickiego $1918 "$ "19.

13 B. Ussas, Akademia Duchowna ..., dz. cyt., kol. 213-214.

14 „Moje pierwsze kontakty z KUL-em były przygodne i odległe, przypominające rolę widza, który z dalszych rzędów obserwuje akcję na scenie, nie bierze jednak w niej udziału, tylko ubocznie styka się z jej czołowymi uczestnikami, ma wgląd w jej przebieg. Nie jest przy tym widzem biernym, ale uczuciowo zaangażowanym. Kontakty te nawiązują do „prehistorii” KUL-u, a pierwsze z nich dotyczą spraw na ogół nieznanych albo tylko ogólnie wzmiankowanych". J. Pastuszka, Akademia Duchowna w Petersburgu 1917-1918. Kontakty z Uniwersytetem Lubelskim 1918-1923, w: Katolicki Uniwersytet Lubelski we wspomnieniach pierwszych studentów z lat 1918-1925, wstęp i red. G. Karolewicz, Lublin 1978, s. 47.

15 W latach 1914-1918 rektorem Akademii Duchownej w Petersburgu był ks. Idzi Radziszewski.

${ }^{16} \mathrm{O}$ braku zrozumienia dla tej idei pisał I. Radziszewski: Uniwersytet katolicki $w$ Polsce, „Wiadomości Towarzystwa Uniwersytetu Lubelskiego” 1 (1923), z. 1, s. 9-24 oraz J. Pastuszka, Ks. Idzi Radziszewski w r. 1917/18. Wspomnienia, „Zeszyty Naukowe Katolickiego Uniwersytetu Lubelskiego" 5 (1962), nr 2 (18), s. 130.

17 Liczono się z możliwością zamknięcia Akademii z powodu wybuchu rewolucji październikowej.

18 Chodzi tu o traktat pokojowy w Brześciu z 3 III 1918 r. między Rosją Radziecką a Niemcami, Austro-Węgrami oraz Bułgarią i Turcją.

19 J. Pastuszka, Akademia Duchowna..., dz. cyt., s. 47-48. 
Trzeba było myśleć o powrocie do kraju i tworzeniu nowej uczelni, aby zastąpić dotychczasową Akademię, w innych tylko wymiarach dostosowanych do potrzeb kraju katolickiego. Powstał wówczas Komitet Organizacyjny przyszłego uniwersytetu katolickiego mimo, że jego tworzenie było połączone $\mathrm{z}$ wieloma niewiadomymi, wynik wojny był także trudny do przewidzenia.

„W Polsce od dawna odczuwano potrzebę uniwersytetu katolickiego - czytamy we wspomnieniach świadka wydarzeń ks. Józefa Pastuszki - ale w okresie rozbiorów pragnienia te nie mogły być urzeczywistnione. Ich realizatorem, stał się ks. Idzi Radziszewski, rektor Akademii Duchownej w Petersburgu, dawny wychowanek Uniwersytetu Katolickiego w Lowanium. Z jego inicjatywy powstał w lutym $1918 \mathrm{r}$. komitet organizacyjny przyszłego uniwersytetu, grupujący szereg polskich uczonych i działaczy. Na czele stanął Karol Jaroszyński, bogaty przemysłowiec, właściciel dużych majątków i kopalni w Rosji. Ten przyrzekł sfinansować założenie uniwersytetu, przeznaczając 300000 rubli na jego utrzymanie w pierwszym roku 1918/1919, a jeden milion na budowę budynków uniwersyteckich. W lipcu 1918 r. wrócił do kraju ks. Idzi Radziszewski i projekt utworzenia uniwersytetu katolickiego przedstawił na Konferencji Biskupów Polskich, jaka się odbyła w dniu 27 lipca [1918 r.] pod przewodnictwem ks. Achillesa Ratti, wizytatora apostolskiego w Polsce, późniejszego papieża Piusa XI. Księża biskupi przyjęli projekt i uchwalili założenie «Uniwersytetu Lubelskiego» w Lublinie ${ }^{20}$, pod wezwaniem Najświętszego Serca Jezusowego i pod hasłem «Deo et Patriae», a rektorem mianowali ks. I. Radziszewskiego. Ówczesne polskie, ale jeszcze okupacyjne, Ministerstwo Oświaty udzieliło prawnego zezwolenia na jego otwarcie.

W końcu września ogłoszono zapisy na uniwersytet. Wykłady rozpoczęto 10 grudnia [1918 r.] w gmachu Seminarium Duchownego w Lublinie, a 9 grudnia odbyła się inauguracja pierwszego roku akademickiego i immatrykulacja ok. 300 studentów, do których należał również ks. Piotr Kałwa, późniejszy biskup lubelski i Wielki Kanclerz KUL. Uruchomiono od razu cztery Wydziały: Teologiczny, Prawa Kanonicznego i Nauk Moralnych, Prawa i Nauk Ekonomiczno-Społecznych oraz Nauk Humanistycznych, z którym złączony został Instytut Pedagogiczny”21.

Dnia 9 grudnia 1918 r. Naczelnik Państwa Józef Piłsudski przesłał depeszę na uroczystość otwarcia Uniwersytetu Lubelskiego ${ }^{22}$. Przy organizacji uniwersytetu ob-

${ }^{20} \mathrm{O}$ wyborze Lublina na siedzibę uniwersytetu wspomina P. Kremer, Ks. Rektor Idzi Radziszewski († 22 lutego 1922 r.), ,Wiadomości Towarzystwa Uniwersytetu Lubelskiego” 1 (1923), z. 1, s. 38-40. W zlokalizowaniu uczelni w Lublinie pomógł ks. Idziemu Radziszewskiemu bp Marian Leon Fulman, były jego profesor z Włocławka. Zob. P. Kremer, Śp. ks. dr Idzi Radziszewski, założyciel i pierwszy rektor Uniwersytetu Katolickiego w Lublinie, ,Kronika Diecezji Kujawsko-Kaliskiej” 16 (1922), s. 502-503.

${ }^{21}$ J. Pastuszka, Powstanie, rozwój i stan obecny Katolickiego Uniwersytetu Lubelskiego 1918-1968, w: Katolicki Uniwersytet Lubelski. 50 lat istnienia i działalności, Lublin 1968, s. 8-9.

22 Zob. J. Piłsudski, Pisma zbiorowe, t. 5, wstęp i red. K. Świtalski, Warszawa 1937, s. 35-36. 
sadzenie kadrą profesorską wydziałów sprawiały wiele trudności, w kraju istniały przed wojną tylko dwa polskie uniwersytety, a ta w ogromnym stopniu przyczyniła się do zmniejszenia kadry naukowej. „Dużą pomoc - wspomina ks. Józef Pastuszka - okazali profesorowie czynnych wtedy uniwersytetów państwowych, zwłaszcza ze Lwowa, którzy dojeżdżali na wykłady i przeprowadzali egzaminy. Na wydziałach kościelnych główną obsadę stanowili dawni profesorowie katolickiej Akademii Duchownej w Petersburgu"23.

W czasie swych studiów w Akademii Józef Pastuszka poznał bliżej ks. Idziego Radziszewskiego ${ }^{24}$, był jego uczniem, z tego czasu zachował o nim żywe wspo-

W Archiwum Uniwersyteckim KUL znajduje się oryginał depeszy Józefa Piłsudskiego: „Dnia 11 stycznia 1920 r. Naczelnik Państwa Józef Piłsudski w drodze powrotnej z Wołynia zatrzymał się Lublinie i przybył do Uniwersytetu Lubelskiego, gdzie spotkał się z ks. rektorem Idzim Radziszewskim, profesorami i studentami. Najpierw podczas spotkania zabrał głos Ksiądz Rektor Uniwersytetu Lubelskiego: „Zawsze każdy z nas Polaków pragnął, aby Polska była wielką i potężną. Ale czyż jeszcze przed kilku dziesięciu laty myśleliśmy, że będzie tak potężną, jaką się obecnie zarysowuje. Czyż przed kilku laty mogliśmy przypuszczać, iż polski Naczelnik Państwa będzie zwiedzał uniwersytet polski w tym mieście prześladowanym przez moskali? Fakty te są tak wielkie i radosne, iż przekroczyły marzenia. Korne za to dzięki Opatrzności [Bożej], a Ciebie witamy z wdzięcznością, na jaką tylko zdobyć się możemy, jaką nam okazałeś do nas przebywając [...]. Jeśli Polska chce być silną, oprzeć się zasadom wywrotnym i fali bolszewizmu musi dbać o wyższe uczelnie, jako środowiska kultury i cywilizacji. W tej myśli złożona została wszechnica lubelska. Działa ona pod hasłem: «Z Bogiem praca dla Ojczyzny». Z Bogiem, bo to hasło ma wielkie, doniosłe znaczenie w dniach budowy Polski. Dla Ojczyzny pracujemy, bo ją całą duszą miłujemy". Po wystąpieniu ks. Idziego Radziszewskiego przemówił przedstawiciel młodzieży akademickiej p. Franciszek Franczak. Po czym zabrał głos Naczelnik Państwa Józef Piłsudski: „Jego Magnificencja dotknął tej mojej słabostki, że pewne rzeczy kocham bardziej [Rektor wspomniał o miłości Piłsudskiego do Wilna], niż inne, z czego jednakże nie należy wyciągać wniosku, abym miał waszą wszechnicę otaczać mniejszą czcią i miłością, niż inne. Albowiem rozumiem, że, jako Naczelnik Państwa, nie mogę być naczelnikiem żadnej grupy lub stronnictwa, ani też jakiegokolwiek miasta: jestem naczelnikiem całego narodu i wszystkich jego warstw. W dzieciństwie moim ciągle mi szeptano w uszy tzn. mądre przysłowia: «Nie dmuchaj pod wiatr!», «Głową muru nie przebijesz!», «Nie porywaj się z motyką na słońce!». Doszedłem później do tego, że silna wola, energia i zapał mogą te właśnie zasady załamać. I obecnie, kiedy stoimy wobec wielkich zadań dalszej budowy państwa polskiego, właśnie potrzeba nam ludzi, którzy potrafią tej starej mądrości przysłów się przeciwstawić...", J. Piłsudski, Pisma zbiorowe..., dz. cyt., s. 133-134. Zob. Naczelnik Państwa w Lublinie, „Ziemia Lubelska” 15 (1920), nr 17 z dnia 13 I 1920 r., s. 1.

23 J. Pastuszka, Powstanie, rozwój..., dz. cyt., s. 9.

24 Por. m.in. opracowania: P. Kremer, Śp. ks. dr Idzi Radziszewski..., art. cyt., s. 111, 123-127, 327-328, 382-390, 441-446, 499-506; A. Pastuszka, X. Rektor Idzi Radziszewski, „Prąd” 16 (1929), s. 159-184; A. Wojtkowski, Ks. Idzi Radziszewski (1871-1922), „,Roczniki Filozoficzne" 1 (1948), s. 228-249; G. Karolewicz, Ksiądz Idzi Radziszewski w oczach pierw- 
mnienia $\mathrm{i}$ opisał je $\mathrm{w}$ czterdzieści lat po jego śmierci ${ }^{25}$. W swoich spostrzeżeniach zachowanych $\mathrm{w}$ pamięci wyraził przekonanie, że zaistniały związki pomiędzy Akademią Duchowną w Petersburgu, która po rewolucji październikowej przestała istnieć, a powołanym do życia w 1918 r. Uniwersytetem Lubelskim. Związki te opierały się na tym, że ,arcybiskup mohylowski, rezydujący w Petersburgu, a będący zwierzchnią władzą duchowną Akademii wystawił dokument, w którym przelał prawa i przywileje Akademii na Uniwersytet Lubelski. Na tej podstawie mógł pisać ks. Idzi Radziszewski do Ministerstwa, że przepisy egzaminacyjne Akademii będą nadal stosowane w Uniwersytecie Lubelskim, a dwa wydziały kościelne są jak gdyby przedłużeniem dawnej Akademii" ${ }^{26}$.

Nadto odnotował, że w Akademii Duchownej ,powstał w roku 1917/1918 plan założenia uniwersytetu katolickiego w Polsce, tam tworzyły się zręby jego organizacji, tam angażowano pierwszych profesorów świeckich, wykładających na uczelniach rosyjskich, a księża profesorowie Akademii przeszli gremialnie do Lublina i tworzyli trzon późniejszego grona profesorskiego na wydziałach kościelnych ${ }^{27}$ Uniwersytetu Lubelskiego"28.

\section{Profesor Katolickiego Uniwersytetu Lubelskiego}

W 1934 r. ks. Józef Pastuszka podjął obowiązki profesora nadzwyczajnego na Wydziale Humanistycznym Katolickiego Uniwersytetu Lubelskiego ${ }^{29}$ wiążąc się $\mathrm{z}$ uczelnią na stałe ${ }^{30}$. W okresie przedwojennym wyjeżdżał kilkakrotnie za granicę (Innsbruck, Paryż, Wiedeń, Monachium) oraz reprezentował Uniwersytet na międzynarodowych zjazdach w Salzburgu (1925 r. zastąpił ówczesnego rektora Antoniego Szymańskiego) i w 1937 r. w Paryżu. W 1935 r. został czynnym członkiem Towarzystwa Naukowego KUL, z czasem współpracownikiem Akademii Umiejętności w Krakowie. W 1938 r. obrano go dziekanem Nauk Humanistycznych i funkcję tę pełnił formalnie do 1947. Z chwilą wybuchu wojny w 1939 r. Uniwersytet

szych studentów KUL, „Biuletyn Informacyjny Katolickiego Uniwersytetu Lubelskiego” 2 (1973), nr 1, s. 5-15.

25 Zob. J. Pastuszka, Ks. Idzi Radziszewski..., dz. cyt., s. 126-131.

26 J. Pastuszka, Ks. Idzi Radziszewski..., dz. cyt., s. 126.

27 J. Pastuszka, Ks. Idzi Radziszewski..., dz. cyt., s. 127.

28 Zob. G. Karolewicz, Katolicki Uniwersytet Lubelski, I. Dzieje, w: Encyklopedia Katolicka, t. 8, Język - Kino, red. B. Migut, Lublin 2000, kol. 1169-1175; J. Ziółek, Katolicki Uniwersytet Lubelski. II. Organizacja, w: Encyklopedia Katolicka, t. 8, Język - Kino, red. B. Migut, Lublin 2000, kol. 1175-1178.

${ }^{29} \mathrm{Na}$ Uniwersytecie Lubelskim pracował jego brat Antoni, był jednym ze studentów z pierwszego rocznika w 1918 r. oraz brat Władysław i Bolesław, którzy ukończyli studia prawnicze i ekonomiczne na KUL-u.

30 Nie przyjął propozycji objęcia katedry na uniwersytecie wileńskim i lwowskim. Dwukrotnie jego działalność była przerwana na kilka lat. Pierwszy raz przez wojnę i okupację (1939-1945), drugi na skutek represji władzy komunistycznej (1952-1956). 
Lubelski przerwał działalność, nastąpiły aresztowania i wywożenia profesorów. Ks. Józef Pastuszka, którego gestapo poszukiwało w Lublinie wyjechał w swe rodzinne strony. Tam jako kapelan sióstr szarytek w Lipowej koło Opatowa, przebył czas okupacji, pełniąc obowiązki duszpasterskie, uczestniczył także w tajnych kompletach nauczania. Jego książki władze niemieckie kazały usunąć z bibliotek za zwalczanie ideologii rasizmu.

Pod koniec wojny, w połowie kwietnia 1945 r., profesor powrócił do Lublina i objął dawną katedrę psychologii ogólnej w Katolickim Uniwersytecie Lubelskim. W styczniu 1946 r. Ministerstwo Oświaty i Nauki Polskiej Rzeczypospolitej Ludowej zatwierdziło jego nominację na profesora zwyczajnego psychologii i filozofii. W tym także roku na KUL-u został otwarty nowy Wydział Filozofii Chrześcijańskiej ${ }^{31}$. Senat Akademicki jego organizację zlecił ks. Józefowi Pastuszce, którego mianował pierwszym dziekanem nowego wydziału przy spełnianiu jeszcze przez rok obowiązków dziekana Wydziału Humanistycznego. Obowiązki profesora psychologii ogólnej i dziekana Wydziału Filozofii Chrześcijańskiej ks. Józef Pastuszka pełnił do września 1952 r. W październiku 1951 r. ks. Antoni Słomkowski zrezygnował z funkcji rektora, wtedy obowiązki rektora podjął ks. Józef Pastuszka i wykonywał przez trzy miesiące. We wrześniu 1952 r. Urząd Bezpieczeństwa usunął go z Uczelni i przez dwa lata prowadził wykłady w Wyższym Seminarium Duchownym w Sandomierzu. Zwolniony pod presją Urzędu Bezpieczeństwa z pracy w seminarium duchownym w Sandomierzu w latach 1954-1956 pracował w Sądzie Diecezjalnym.

W 1956 ks. Józef Pastuszka powrócił do Lublina na KUL, gdzie zorganizował studium psychologii i w latach 1957-1969 był przewodniczącym Specjalizacji Filozoficzno-Psychologicznej ${ }^{32}$. Nadto w ramach Towarzystwa Naukowego KUL utworzono Komisję Psychologiczną, której objął kierownictwo od 29 IV 1964 r. i sprawował do 11 czerwca $1970^{33}$. Jednocześnie do 1966 r. został kuratorem Studenckiego Koła Psychologów. W tym okresie $(1961,1965)$ podjął trud przygotowania konferencji naukowych dla wykładowców filozofii chrześcijańskiej.

Praca dydaktyczna księdza profesora na Wydziale Filozofii Chrześcijańskiej od 1957 r. obejmowała wykłady każdego roku z psychologii ogólnej, a okresowo wykłady z dziedziny charakterologii i psychologii społecznej oraz wykład monograficzny

31 J. Pastuszka, Wydział Filozofii Chrześcijańskiej przy Katolickim Uniwersytecie Lubelskim. Jego potrzeba, stan obecny i zadania, „Ateneum Kapłańskie” 39 (1947), t. 47, s. 82-87; J. Pastuszka, Poczatki Wydziału Filozofii Chrześcijańskiej KUL, Z okazji XX-lecia Wydziału (1946-1966), „Zeszyty Naukowe Katolickiego Uniwersytetu Lubelskiego” 10 (1967), nr 2, s. 77-79.

32 J. Pastuszka, Specjalizacja Filozoficzno-Psychologiczna na Wydziale Filozofii Chrześcijańskiej, „Roczniki Filozoficzne” 13 (1965), z. 4, s. 155-162.

33 Z. Sułowski, D. Noskowska, Towarzystwo Naukowe Katolickiego Uniwersytetu Lubelskiego, w: Księga pamiątkowa w 75-lecie Katolickiego Uniwersytetu Lubelskiego. Wkład w kulture polska w latach 1968-1993, red. M. Rusecki, Lublin 1994, s. 674. 
historii psychologii. Nadto prowadził seminarium dla magistrantów (2 godz. tygodniowo) i doktorantów (1 godz.). Jego zainteresowania naukowe skupiały się wokół psychologii filozoficznej. Prowadził także wykłady z psychologii duszpasterskiej i na Wydziale Nauk Humanistycznych, etykę na tle współczesnych kierunków umysłowych.

Ksiądz profesor obok bogatego dorobku pisarskiego, pozostawił pamięć wybitnego uczonego-profesora, wychowawcy wielu pokoleń młodzieży, dla której umiał być również przyjacielem. W czerwcu 1969 r. Senat Akademicki Katolickiego Uniwersytetu Lubelskiego w dowód uznania zasług ks. Józefa Pastuszki nadał mu tytuł profesora honorowego.

\section{Emerytowany profesor}

W lipcu 1969 r. przeszedł na emeryturę, przez wiele lat mieszkał nadal w konwikcie księży przy KUL-u. Dnia 15 sierpnia 1969 r., ksiądz profesor obchodził złoty jubileusz kapłaństwa, 35 lat profesury na KUL-u i 48 lat profesury łącznie na Katolickim Uniwersytecie Lubelskim i Uniwersytecie Warszawskim i trzech wyższych seminariach duchownych (Sandomierz, Warszawa, Lublin). Z tej okazji poświęcono mu numer 4 ,Roczników Filozoficznych” z dedykacją:

Twórcy i Kierownikowi

Specjalizacji Filozoficzno-Psychologicznej,

Kierownikowi Katedry Psychologii Ogólnej

Wydziału Filozofii Chrześcijańskiej KUL,

Przewodniczącemu Komisji Psychologicznej TN KUL,

Redaktorowi Naczelnemu Działu Psychologii

„Roczników Filozoficznych”,

Nauczycielowi oraz Wychowawcy,

Profesorowi Doktorowi Józefowi Pastuszce

z okazji 35-lecia profesury

na Katolickim Uniwersytecie Lubelskim

oraz 50-lecia kapłaństwa

prace swe dedykują

współpracownicy i uczniowie

Dnia 13 kwietnia 1970 r. kard. Stefan Wyszyński pisał do ówczesnego rektora Katolickiego Uniwersytetu Lubelskiego ks. Wincentego Granata: „Ksiądz Profesor Józef Pastuszka należy do tych wyjątkowych ludzi, którzy dochowali wierności Uczelni do końca. Śmiało można go postawić obok ks. rektora Radziszewskiego, ks. rektora Kruszyńskiego, ks. rektora Słomkowskiego, profesora Ignacego Czumy i innych, którzy kochali Uczelnię i życie jej poświęcili. A wiadomo, że Katolicki Uniwersytet Lubelski to nie jest tylko sprawa posady i pracy. To jest osobisty stosunek, który jest twórczy i ofiarny" 34 .

34 Archiwum Uniwersyteckie [dalej: AU] KUL, sygn. A-299, Referat Personalny, Akta osobowe ks. Józefa Pastuszki, Pismo Prymasa Polski N. 700/70/P. 
W 1978 r. Katolicki Uniwersytet Lubelski odchodził 60-lecie swego istnienia. Z tej okazji Wydział Filozofii Chrześcijańskiej zorganizował 28 czerwca 1978 r. dyskusję nad swym dorobkiem ${ }^{35}$. Celem dyskusji była refleksja nad pracą środowiska. Próbowano przypomnieć sobie funkcje i zadania w zakresie organizacyjno-dydaktyczno-naukowym na Wydziale jako całości i na czterech specjalizacjach: filozofii teoretycznej, społecznej, filozoficzno-psychologicznej i filozofii przyrody. Pod koniec dyskusji przemówił ks. Józef Pastuszka, który był u początków Wydziału: „Zawsze czułem się bliski, związany z Uniwersytetem, a zwłaszcza z Wydziałem Filozofii Chrześcijańskiej, a szczególnie z psychologią. Ponieważ niedługo, za tydzień, opuszczam w ogóle Lublin i KUL, pozwolę sobie więc tu, ponieważ do pewnego stopnia zebrani są przedstawiciele wszystkich sekcji, wszystkich specjalizacji, są szczyty Uniwersytetu w osobie Księdza Rektora, pozwolę sobie złożyć podziękowanie wszystkim za współpracę przez wiele, wiele lat, a tak samo składam jak najlepsze życzenia rozwoju dla Wydziału, nowych sukcesów, nowych zdobyczy, żeby ten Wydział, który rzeczywiści z tak małego ziarnka wyrastał, żeby się jeszcze bardziej rozrósł i żeby coraz bardziej oddziaływał na życie kulturalne Polski, a szczególnie na naukę katolicką. Niech mi wolno będzie złożyć życzenia na ręce Księdza Rektora - wszystkiego najlepszego. I wszystkich Państwa żegnam, a tym samym i Wydział. Chciałbym, ażeby moja wypowiedź była traktowana w pewnym stopniu jako symboliczne pożegnanie całego Wydziału"36.

Profesor w 1978 r. opuścił Lublin i zamieszkał w domu kapitulnym w Sandomierzu. Dnia 23 maja 1984 r. podczas publicznego zebrania Towarzystwa Naukowego KUL, z okazji 50. rocznicy jego powstania, wręczono ks. Józefowi Pastuszce, wieloletniemu dziekanowi Wydziału Filozofii Chrześcijańskiej i profesorowi Katolickiego Uniwersytetu Lubelskiego, Nagrodę im. Księdza Idziego Radziszewskiego, założyciela KUL-u, przyznawaną przez Zarząd Towarzystwa Naukowego Katolickiego Uniwersytetu Lubelskiego „za wybitne osiągnięcia naukowe w duchu humanizmu chrześcijańskiego". Laudację przedstawił ks. doc. dr Władysław Prężyna, który w swej wypowiedzi mówił o całokształcie jego pracy uniwersyteckiej wyodrębniając trzy płaszczyzny: myśli naukowej, udziału w organizacji nauki i aktywności w udostępnianiu zdobytej wiedzy innym ${ }^{37}$. Następnie Laureat wygłosił wykład: „Trzy typy egzystencjalistycznej koncepcji człowieka: S. Kierkegaard, M. Heidegger i J. P. Sartre" 38 .

35 Zob. S. Majdański, W kręgu filozofii Katolickiego Uniwersytetu Lubelskiego. Z dyskusji o dorobku Wydziału Filozofii Chrześcijańskiej z okazji 60-lecia Uczelni, „Życie i Myśl” 28 (1978), nr 11, s. 21-72.

36 S. Majdański, $W$ kręgu..., dz. cyt., s. 71.

37 Zob. „Biuletyn Informacyjny Katolickiego Uniwersytetu Lubelskiego” 13 (1984), nr 1-2 (25-26), s. 83-92.

38 J. Cieszkowski, Diariusz wydarzeń uniwersyteckich, kwiecień-czerwiec 1984, „Zeszyty Naukowe Katolickiego Uniwersytetu Lubelskiego" 27 (1984), nr 2 (106), s. 80. 


\section{Zakończenie}

Po prezentacji osoby ks. Józefa Pastuszki przedstawione zostały jego relacje z Akademią Duchowną w Petersburgu i z tworzącym się w 1918 r. Uniwersytetem Lubelskim. Był on ostatnim z absolwentów Akademii Duchownej w Petersburgu i uczniów założyciela i pierwszego rektora katolickiej uczelni w Lublinie ks. Idziego Radziszewskiego.

Z czasem po skończeniu studiów w Innsbrucku i pracy na Uniwersytecie Warszawskim profesor zwyczajny filozofii i psychologii ks. Józef Pastuszka podjął wieloletnią pracę profesorską na katolickiej uczelni i dobrze jej się przysłużył; zaliczany jest do grona zasłużonych reprezentantów polskiej filozofii chrześcijańskiej okresu międzywojennego i powojennego. W jego nekrologu napisano: „Był wielkim przyjacielem młodzieży i znakomitym wychowawcą wielu jej pokoleń; człowiek i kapłan niezwykle zasłużony dla Katolickiego Uniwersytetu Lubelskiego, z którym czynną pracą naukową i dydaktyczną związany był od 1932 do 1978 r. Współtwórca Wydziału Filozofii Wydziału Filozofii Chrześcijańskiej po II wojnie światowej i jego dziekan w latach 1947-1952, a wcześniej dziekan Wydziału Nauk Humanistycznych 1938-1947 (z przerwą na lata okupacji). Po aresztowaniu w 1951 r. ks. rektora Antoniego Słomkowskiego przez 3 miesiące pełnił funkcję rektora KUL, dopóki sam nie został poddany represjom. W osobie ks. profesora Józefa Pastuszki Katolicki Uniwersytet Lubelski traci jednego z najbardziej zasłużonych swoich pracowników [...]. - Rektor, Senat Akademicki, Rada Wydziału Filozofii Chrześcijańskiej, Rada Wydziału Nauk Społecznych, młodzież akademicka i pracownicy Katolickiego Uniwersytetu Lubelskiego"39.

\section{Aneks}

List Dyrekcji Zespołu Szkół im. ks. Józefa Pastuszki w Rzeczniowie do Haliny Ireny Szumił z dnia 5 kwietnia 2019 r.

Dnia 18 września 2005 r. Zespół Szkół w Rzeczniowie obrał za patrona placówki swego Rodaka ks. prof. dr. hab. Józefa Pastuszkę. Corocznie obchodzi jego święto oraz gromadzi wielu znakomitych gości - jego uczniów, przyjaciół oraz rodzinę, stając się okazją do wspomnień o wielkim człowieku i wybitnym duszpasterzu. Swoją obecnością uświetniają uroczystość przedstawiciele KUL-u, WSD w Sandomierzu i Radomiu, Urzędu Marszałkowskiego Województwa Mazowieckiego, Delegatury Kuratorium Oświaty w Radomiu oraz lokalnych władz, urzędów i instytucji. Rodzina ks. prof. dr. hab. Józefa Pastuszki jest fundatorem nagród w organizowanych konkursach wiedzy o patronie, które przybliżają dzieciom i młodzieży sylwetkę znakomitego rzeczniowianina. Stałym elementem obchodów jest sprawowana tego dnia Msza święta z udziałem przedstawicieli najwyższych władz kościelnych oraz występ artystyczny w wykonaniu uczniów szkoły. Dyrekcja placówki we współpra-

39 AU KUL, sygn. A-299, Referat Personalny, Akta osobowe ks. Józefa Pastuszki. Nekrolog. 
cy z władzami samorządowymi dbają o należytą oprawę uroczystości, która buduje poczucie dumy i przynależności do społeczności małej ojczyzny. Przesłanie płynące z przekonania patrona o znaczeniu wychowania młodego człowieka jednoznacznie utożsamianego z okazywaną mu pomocą zawiera tablica upamiętniająca sylwetkę kapłana umieszczona przy wejściu do budynku szkoły. Zgromadzone na szkolnej stałej wystawie pamiątki po ks. prof. Józefie Pastuszce każdego dnia przypominają o jego osobie, naukowym dorobku i zwykłym życiu duchownego, który za oręż miał różaniec i skromną komżę.

Postać ks. prof. Józefa Pastuszki dla społeczności szkolnej Zespołu Szkół im. ks. Józefa Pastuszki w Rzeczniowie jest nietuzinkowa. Duchowny z pasją, skromny syn wychowany w domu wrażliwych, mądrych ludzi, pedagog, wykładowca, przewodnik młodzieży szukającej Boga - oto najkrótszy opis patrona rzeczniowskiej szkoły. Z czego wynika wyjątkowość tego człowieka? Przede wszystkim z faktu, że niczym biblijny Józef - człowiek zawierzenia, który z pokorą przyjmuje swoje powołanie, w milczeniu realizował Boży plan. Nie rzucał się w oczy, nie krzyczał, nie nawoływał, ale z miłością wypełniał życiowe zadania. Ujmujące są cierpliwość i wierność wartościom Księdza Profesora, który mimo wielu trudności i wbrew wojennej zawierusze kształcił się, dając tym samym przykład młodym ludziom, że warto dbać o własny rozwój. Namacalnym dowodem na to są naukowe dokonania ks. Józefa Pastuszki - jego publikacje stanowiące dziś wykładnię pracy kolejnych pokoleń studentów. Kapłan urodzony w małej wsi udowodnił, że można być wielkim, będąc jednocześnie zwyczajnym. W każdym człowieku dostrzegał Boga, szukał drogi do niego, wielokrotnie powtarzając, że ,jest wielką głębią”. To z takich właśnie powodów zyskał miano autorytetu i od czternastu już lat patronuje uczniom Zespołu Szkół w Rzeczniowie. Dnia 18 września 2005 roku została odprawiona Msza święta pod przewodnictwem ks. infułata Józefa Wójcika, który dokonał poświęcenia sztandaru szkoły. Był to niezwykle wzruszający moment ze względu na rangę celebransa - proboszcza parafii św. Andrzeja Apostoła w Suchedniowie, duchownego więzionego w czasach PRL-u za obronę krzyży usuwanych ze szkół, który w 1972 r. wsławił się uwolnieniem kopii obrazu Matki Bożej Jasnogórskiej więzionej na skutek decyzji komunistycznych władz od $1966 \mathrm{r}$.

W swym życiorysie Ksiądz Profesor napisał: „W moim życiu połączyłem dwa powołania - kapłaństwo i profesurę. Było to powiązanie szczęśliwe, które wypełniło mi życie. Moje kapłaństwo połączyłem z pracą intelektualną, naukową. Obie te funkcje nie były dowolnie wybrane, ale jakby narzucone przeze mnie samego, gdyż obie były wyrazem mojej osobowości, obie się uzupełniały. Nigdy nie żałowałem, że zostałem kapłanem i profesorem, bo wiem komu uwierzyłem" ${ }^{40}$. Słowa te świadczą o prawdzie człowieka spełnionym i szczęśliwym, mówią o człowieku mającym

40 Cyt. za H. I. Szumił, W stużbie nauki. Ksiądz Józef Pastuszka (1897-1989), Sandomierz 2018, s. 30 . 
jasno określone zasady moralne, zakorzenionym w tradycji swoich pradziadów. Jedynie tacy ludzie mogą stanowić drogowskaz, kształtując nowe pokolenia.

Dyrekcja Zespołu Szkół im. ks. Józefa Pastuszki

Rzeczniów, 5 kwietnia 2019 r.

\section{BIBLIOGRAFIA}

\section{Źródła archiwalne:}

\section{Archiwum Diecezji Sandomierskiej:}

Akta personalne ks. Józefa Pastuszki (1897-1989).

\section{Archiwum Uniwersyteckie KUL:}

sygn. A-299, Akta osobowe ks. Józefa Pastuszki (1897-1989).

\section{Źródła drukowane:}

Cieszkowski J., Diariusz wydarzeń uniwersyteckich, kwiecień-czerwiec 1984, „Zeszyty Naukowe Katolickiego Uniwersytetu Lubelskiego" 27 (1984), nr 2 (106), s. 80 .

(las), Uroczystości pogrzebowe śp. ks. prof. J. A. Pastuszki, „Słowo Powszechne” 42 (1989), nr 15, z dnia 20 I 1989 r., s. 1, 6.

Lewiński J., Kronika $-z$ życia diecezji, „Kronika Diecezji Sandomierskiej” 82 (1989), nr 3-4, s. 87-88.

Pastuszka J., Ks. Idzi Radziszewski wr. 1917/18. Wspomnienia, „Zeszyty Naukowe Katolickiego Uniwersytetu Lubelskiego" 5 (1962), nr 2, s. 129-130.

Pastuszka J., Sandomierskie wspomnienia szkolne z lat 1908-1912, do druku przygotował J. M. Małecki, „Studia Historyczne” 29 (1965), s. 595-619.

Piłsudski J., Pisma zbiorowe, t. 5, wstęp i red. K. Świtalski, Warszawa 1937.

\section{Opracowania:}

(c. b.), Zmart ks. prof. prałat Józef Adam Pastuszka, „Słowo Powszechne” 42 (1989), nr 12, z dnia 17 I 1989 r., s. 6.

Karolewicz G., Ksiądz Idzi Radziszewski w oczach pierwszych studentów KUL, „Biuletyn Informacyjny Katolickiego Uniwersytetu Lubelskiego” 2 (1973), nr 1, s. 5-15.

Karolewicz G., Katolicki Uniwersytet Lubelski, I. Dzieje, w: Encyklopedia Katolic$k a$, t. 8, Język - Kino, red. B. Migut, Lublin 2000, kol. 1169-1175. 
Kremer P., Ks. Rektor Idzi Radziszewski († 22 lutego 1922 r.), „Wiadomości Towarzystwa Uniwersytetu Lubelskiego" 1 (1923), z. 1, s. 38-40.

Kremer P., Śp. ks. dr Idzi Radziszewski, założyciel i pierwszy rektor Uniwersytetu Katolickiego w Lublinie, „Kronika Diecezji Kujawsko-Kaliskiej” 16 (1922), s. 502-503.

Kuty P. K., Ziemiński I., Diariusz wydarzeń uniwersyteckich, styczeń-grudzień 1989, „Zeszyty Naukowe Katolickiego Uniwersytetu Lubelskiego” 32 (1989), nr 1-4, s. 131-132.

Majdański S., W kręgu filozofii Katolickiego Uniwersytetu Lubelskiego. Z dyskusji o dorobku Wydziału Filozofii Chrześcijańskiej z okazji 60-lecia Uczelni, „Życie i Myśl” 28 (1978), nr 11, s. 21-72.

Pastuszka A., X. Rektor Idzi Radziszewski, „Prąd” 16 (1929), s. 159-184.

Pastuszka J., Akademia Duchowna w Petersburgu 1917-1918. Kontakty z Uniwersytetem Lubelskim 1918-1923, w: Katolicki Uniwersytet Lubelski we wspomnieniach pierwszych studentów z lat 1918-1925, wstęp i red. G. Karolewicz, Lublin 1978, s. 47-53.

Pastuszka J., Poczatki Wydziału Filozofii Chrześcijańskiej KUL, Z okazji XX-lecia Wydziału (1946-1966), „Zeszyty Naukowe Katolickiego Uniwersytetu Lubelskiego" 10 (1967), nr 2, s. 77-79.

Pastuszka J., Powstanie, rozwój i stan obecny Katolickiego Uniwersytetu Lubelskiego 1918-1968, w: Katolicki Uniwersytet Lubelski. 50 lat istnienia i działalności, Lublin 1968, s. 7-36.

Pastuszka J., Psychologia ogólna, Lublin 1961.

Pastuszka J., Specjalizacja Filozoficzno-Psychologiczna na Wydziale Filozofii Chrześcijańskiej, „Roczniki Filozoficzne” 13 (1965), z. 4, s. 155-162.

Pastuszka J., Wydział Filozofii Chrześcijańskiej przy Katolickim Uniwersytecie Lubelskim. Jego potrzeba, stan obecny i zadania, „Ateneum Kapłańskie” 39 (1947), t. 47 , s. $82-87$.

$\mathrm{P}$ [astuszka] J., Z życia parafialnego. Sandomierz. Święto narodowe, „Kronika Diecezji Sandomierskiej" 18 (1925), s. 130-132.

Radziszewski I., Uniwersytet katolicki w Polsce, „Wiadomości Towarzystwa Uniwersytetu Lubelskiego" 1 (1923), z. 1, s. 9-24.

Sułowski Z., Noskowska D., Towarzystwo Naukowe Katolickiego Uniwersytetu Lubelskiego, w: Ksiega pamiatkowa w 75-lecie Katolickiego Uniwersytetu Lubelskiego. Wktad w kulture polska w latach 1968-1993, red. M. Rusecki, Lublin 1994, s. 665-675.

Szumił H. I., W stużbie nauki. Ksiądz Józef Pastuszka (1897-1989), Sandomierz 2018.

Ussas B., Akademia Duchowna w Petersburgu, w: Encyklopedia Katolicka, t. 1, 
A i $\Omega$ - Babtyści, red. F. Gryglewicz, R. Łukaszczyk, Z. Sułowski, Lublin 1995, kol. 213-214.

Wojtkowski A., Ks. Idzi Radziszewski (1871-1922), „Roczniki Filozoficzne” 1 (1948), s. 228-249.

Ziółek J., Katolicki Uniwersytet Lubelski. II. Organizacja, w: Encyklopedia Katolicka, t. 8, Język-Kino, red. B. Migut, Lublin 2000, kol. 1175-1178.

\section{Streszczenie}

Przyszły profesor Katolickiego Uniwersytetu Lubelskiego, ks. Józef Adam Pastuszka, w 1912 r. rozpoczął studia w Wyższym Seminarium Duchownym w Sandomierzu i realizował je do pierwszej wojny światowej, która w następstwie działań wojennych w 1915 r. wraz z rodzicami i rodzeństwem zaprowadziła go na Wschód w okolice Brześcia. Kiedy udało mu się przedostać do Petersburga, podjął przez dwa lata kontynuację studiów w tamtejszym seminarium duchownym. Po czym przez rok 1917/1918 był studentem Akademii Duchownej w Petersburgu, gdzie miała swój początek, niejako „prehistorię” uczelnia lubelska. Rektorem Akademii był wówczas ks. Idzi Radziszewski.

W roku 1917/1918 ówczesny rektor Akademii w Petersburgu podjął organizację Uniwersytetu Lubelskiego. W swoich wspomnieniach ks. Józef Pastuszka wyraził przekonanie, że zaistniały związki pomiędzy Akademią Duchowną w Petersburgu, która po rewolucji październikowej przestała istnieć, a powołanym do życia w 1918 r. Uniwersytetem Lubelskim. Związki te opierały się na tym, że rezydujący w Petersburgu arcybiskup mohylowski, jako zwierzchnia władza Akademii, przelał prawa i przywileje Akademii na Uniwersytet Lubelski.

W lipcu 1918 r. jako subdiakon Józef Adam Pastuszka wrócił do kraju. Mając ukończony pierwszy rok studiów w Petersburgu został przez sandomierską władzę diecezjalną skierowany na studia do Innsbrucka (Austria). Pod koniec października 1920 r. otrzymał dyplom doktorski, a 1930 przeprowadził colloquium habilitacyjne na Uniwersytecie Jagiellońskim i uzyskał tytuł docenta filozofii i podjął pracę na Wydziale Teologicznym Uniwersytetu Warszawskiego. W 1934 r. został zatrudniony na Wydziale Humanistycznym Katolickiego Uniwersytetu Lubelskiego. Z chwilą wybuchu wojny w 1939 r. Uniwersytet Lubelski przerwał działalność. W połowie kwietnia 1945 r. Profesor powrócił do Lublina i objął dawną katedrę psychologii ogólnej w Katolickim Uniwersytecie Lubelskim. We wrześniu 1952 r. został usunięty z Uczelni. W 1956 ks. Józef Pastuszka znów powrócił do pracy na KUL.

W lipcu 1969 r. przeszedł na emeryturę, w 1978 r., opuścił Lublin i zamieszkał w domu kapitulnym w Sandomierzu. Zmarł 13 stycznia 1989 r. w Sandomierzu, 17 stycznia w katedrze sandomierskiej odbyły się uroczystości pogrzebowe, 21 stycznia 1989 r. został pochowany w rodzinnej parafii Rzeczniowie. 
Słowa klucze: ks. Józef Pastuszka, ks. Idzi Radziszewski, Akademia Duchowna w Petersburgu, Katolicki Uniwersytet Lubelski

\section{The Relationship Between Fr. Józef Pastuszka, the Spiritual Academy of St. Petersburg, and the Catholic University of Lublin}

\section{Summary}

The future Professor of the Catholic University of Lublin, Fr. Józef Adam Pastuszka, in 1912, began studies at the Theological Seminary in Sandomierz and continued them until the First World War. It was then, after the hostilities of 1915, that he was, together with his parents and siblings, moved to the East near Brest. When he managed to get to St. Petersburg, he continued his studies at the local seminary for two years. During the year 1917-1918, he was a student at the Spiritual Academy of St. Petersburg, where the University of Lublin had its beginning, a kind of "prehistory." Fr. Idzi Radziszewski was the Academy's rector.

In 1917-1918, the rector of the Academy of St. Petersburg undertook the organization of the University of Lublin. In his memories, Fr. Józef Pastuszka expressed his conviction that there existed connections between the Spiritual Academy of St. Petersburg, which ceased to exist after the October Revolution, and the Catholic University of Lublin, established in 1918. These relations were based on the fact that the Archbishop of Mohilev, residing in St. Petersburg as the superior authority of the Academy, transferred the rights and privileges of the Academy to the University of Lublin.

In July 1918, as a subdeacon, Józef Adam Pastuszka returned to Poland. Having completed his first year of study in St. Petersburg, he was directed by the diocesan authorities in Sandomierz to study in Innsbruck (Austria). At the end of October 1920, he received a doctoral degree, and in 1930 he conducted a post-doctoral colloquium at the Jagiellonian University, obtained the title of Associate Professor of Philosophy, and took a job at the Faculty of Theology of the University of Warsaw. In 1934, he was employed at the Faculty of Humanities at the Catholic University of Lublin. When the war broke out in 1939, the University of Lublin was closed. In mid-April 1945, the professor returned to Lublin and took up the former chair of general psychology at the Catholic University of Lublin. In September 1952, he was removed from the University. In 1956, Józef Pastuszka returned to work at the Catholic University of Lublin again.

In July 1969 he retired, while in 1978 he left Lublin to live in the chapter house in Sandomierz. He died on January 13, 1989 in Sandomierz, and on January 17, funeral ceremonies took place in the Cathedral of Sandomierz. On January 21, 1989 he was buried in the home Parish of Rzeczniów.

Key words: Fr. Józef Pastuszka, Fr. Idzi Radziszewski, the Spiritual Academy of St. Petersburg, the Catholic University 